\title{
The Influence of Vlog toward the Political Image and Elektability of Joko Widodo in President Election (Pilpres) 2019 (Survey of Postgraduate Students of Mercu Buana University, Jakarta)
}

\author{
${ }^{1}$ Fakultas Ilmu Komunikasi, Universitas Mercu Buana, Indonesia \\ ${ }^{2}$ Fakultas Ilmu Komunikasi, Universitas Mercu Buana, Indonesia \\ ${ }^{3}$ Fakultas Ilmu Komunikasi, Universitas Mercu Buana, Indonesia \\ ${ }^{4}$ Fakultas Ilmu Komunikasi, Universitas Pancasila, Indonesia
}

Afdal Makkuraga Putra ${ }^{1 *}$, Ahmad J. Islami ${ }^{2}$, Dicky Andika ${ }^{3}$, Muh Rosit ${ }^{4}$

*Corresponding author: Afdal Makkuraga Putra

\section{Abstract}

A long with the digitalization of Youtube became an alternative means of campaigning for politicians before the general election. President Joko Widodo (Jokowi) used this video application to increase his popularity and, at the same time, socialize his political activities over the past 5 years. Through Youtube, Jokowi presents his daily activities as president, for example thr household activities and activities as President of the Republic of Indonesia. The researcher wanted to examine how much the influence of President Jokowi's Video Blog (Vlog) toward the Political image and Electability for the 2019 Presidential Election. This study intended to examine the validity of the S-O-R theory on the situation of social media booming. The method used was a survey method, with data collection techniques through questionnaires distributed to 221 respondents. The results showed that the variable of political image and a correlation value have 0.593 which produced an effect of $35.2 \%$. While the coefficient of determination of the electability variable has 0.393 which resulted an effect of $15.5 \%$. This means that $35.2 \%$ of the political image variable and $15.5 \%$ of the electability variable are contributed from the jokowi vlog variable. Whereas $49.3 \%$ can be explained or influenced by other variables which are not examined by the present researcher.

Keywords: Political Campaign, Video Blog, Political Imagery, electability.

Copyright @ 2020: This is an open-access article distributed under the terms of the Creative Commons Attribution license which permits unrestricted use, distribution, and reproduction in any medium for non-commercial use (NonCommercial, or CC-BY-NC) provided the original author and source are credited.

\section{INTRODUCTION}

2019 is a political year as well as a year of modern political history in Indonesia. In 2019, for the first time Indonesia will hold a Legislative Election as well as a Presidential Election simultaneously. Previous elections for the legislative and presidential elections were held at different times.

Presidential Election Contestants also utilize all resources and social media facilities to conduct socialization and campaigns to gain support and sympathy. One of the social media used is YouTube. Youtube is social media platform that allows users to upload videos and view videos uploaded by others. As time goes by, YouTube is busy being used as a means of campaigning.

This study wants to find a correlation between Joko Widodo (Jokowi) vlog on Youtube of political image and electability. The researcher used the Organism Response Stimulus theory or abbreviated SO-R. Since 1930s, a classic model of communication was born which was heavily influenced by psychological theory, namely S-O-R (StimulusOrganism-Response). The basic assumption of this model shows that communication is an action-reaction. This means that this model assumes that a word is verbal, cues is non-verbal, certain symbols will stimulate others to respond in certain ways. The cause of changes in behavior depends on the quality of the stimulus that communicates with the organism. This means that the quality of the source of communication (source) such as credibility, leadership, style of speech really determine the success of behavior changes in someone, group or community.

Although classified as a classic, this theory is still relevant to be studied. A research comducted by Chen Peng and Yeong Gug Kim [1] shows that S-O-R 
theory is still widely used. Cheng and Yeong's study used the Stimuli-Organism-Response framework to examine how consumers' reasons for shopping and website stimulation influence their attitude to online shopping, their ability manages emotional purchases, and repurchase intentions. The results of a survey of 416 eligible respondents were analyzed using structural equation modeling. The survey results show that (1) the value of hedonic shopping has a positive effect on consumer attitudes toward online shopping and emotional purchases, (2) the value of utilitarian spending has a significant influence on consumer attitudes towards online shopping, (3)) environmental stimuli positively influence consumer attitudes towards online shopping and emotional buying, and (4) consumer attitudes toward online shopping positively influence their repurchase intentions. However, there is no significant relationship between the value of utilitarian spending and emotional purchases or between emotional purchases and repurchase intentions.

Chen and Yeong's research was strengthened by the research of Muhammad Umer et al., [2]. Umer conducted research on the determinants of Online Consumer Compulsive Behavior using S-O-R theory. The results showed that social factors significantly contributed to psychological factors. Likewise, perceived enjoyment has a significant influence on the development of a consumer's urge to buy and the compulsive buying behavior. Online compulsive buying via internet / mobile is not intensively studied in the literature today, despite significant use for customers, managers, academics and marketers. In addition, this research contributes to the fields of online commerce, marketing, retail, and mobile learning research.

Research, which was conducted by Hyowon Hyun, Jungkung Park, Tianbao Ren, and Hyunin Kim [3] also found that the S-O-R theory was still relevant. Hyowon et al., [3] who examined the role of atmosphere and aesthetics in the behavior of museum visits for millennials in South Korea showed that Korean millennial visitors pursued hedonic values rather than utilitarian values when they visited art museums. It turns out that hedonic values accelerate visitor satisfaction and promote visitor loyalty more than utilitarian value in an art museum setting. The atmosphere and aesthetics play a stimulating role in the context of art museums and moderate the relationship between values, satisfaction and loyalty felt by visitors. Utilitarian value is identified as unimportant elements for young Korean museumgoers.

Likewise, the research of Umonrat Segson and Chai Ching Tan [4]. Their study adapted and tested the stimulus-organism-response (S-O-R) theory in the context of upper-class restaurants in Northern Thailand, which made a significant contribution by separating stimuli into restaurant inducements and attitudes. The attitude level adapts planned behavior theory with an expanded emphasis on attitudes induced by social media to reflect contemporary norms of social lifestyle. The restaurant-induced stimulus considers the quality of service and food, and the atmosphere of the restaurant. This stimulus will be studied because of their ability to predict various types of customer values namely economic value, hedonic value and functional value, and brand image, customer satisfaction and brand trust known as organisms. The response includes another very neglected factor known as sharing experiences especially useful for marketers to exploit the creation of brand awareness and the effects of externalities. Therefore, this research will add significantly to the body of knowledge by exploiting S-O-R theory in the social media environment. Sampling is based on convenience, with a focus on customers who have visited high-end restaurants in Northern Thailand. Judging from the various hypotheses proposed, correlation, hierarchical multiple regression, and structural equation modeling (SEM) will be the main statistical analysis method.

The rapid development of the internet has produced a new medium for internet users to share and interact with one another, namely social networking or often called social media. There are various kinds of social networks, such as Facebook, Twitter, YouTube, Path, Instagram and many more. Based on the survey results from the leading survey website Alexa.com in 2018, Youtube ranks first in the Top Global most visited sites, with a total of 36 million visitors every day, followed by Facebook behind it with a total of 24 million visitors every day. In Indonesia, Youtube ranks first as the most visited social media.

As it is popular in Indonesia, Youtube provides a feature of watching and sharing videos, through Youtube, its users can also get income from Youtube, it all happens when we upload videos on Youtube and meet the requirements to promote some advertisements which become the coffers of our income from uploading videos on Youtube. Nowadays, a lot of people are looking for income through Youtube, and they are usually called Vlogger, where it comes from the word Vlog or Video Blog.

Research about Youtube as a campaign media has often been conducted, for example, Lucia Vesnic Alujevic [5]. Lucia's research on the role of social media in political communication in Europe, with special interest in the election of the European Parliament. Lucia conducts research with a focus on political campaigns through YouTube that are made to attract the attention of citizens. The initial adaptation is related to the appearance of social media and usergenerated content. As the number of users of social networking sites in Europe continues to grow, 2009 was the first time that this website was used in political marketing purposes for European Parliament elections. The research method used was an exploratory study of 
the nature and level of video-based social media, studied through analysis of YouTube video content made for election campaigns for the European Parliament 2009. The election of European Parliament was attended by 13 political parties from four European Union countries. The results show the peculiarities of political advertising on YouTube, increasing interest in social media among citizens in Europe, and the development of the way this campaign is.

The research of Itai Himelboim, Ruthann Weaver Lariscy, Spencer F. Tinkham, and Kaye D. Sweetser [6] entitled Social Media and Online Political Communication: The Role of Interpersonal Informational Trust and Openness. In this study, researchers wanted to find out the relationship between interpersonal information trust and openness with internet-based political activities and attitudes. The result of the study is a belief that interpersonal information was found to be positively related to the perception of online activities as political participation. It is also associated with the use of all types of online media for political communication purposes, but mostly with online spaces that require interaction with others. Interpersonal political openness shows a positive relationship with the use of interactive type websites for political communication purposes

Wei-Chun Wen's research [7] titled Facebook political communication in Taiwan: 1.0 / 2.0 messages and election / post-election messages. In this study, researchers wanted to find out the influence of political messages on Facebook, based on the research results obtained, general campaign message patterns, extend understanding of political communication on Facebook, and challenge the politics of the concept of a permanent campaign. First, the Facebook message of the candidates for the 2012 Taiwan presidential election confirms that the general pattern has more praise, few attacks, and rare defenses is one of the three basic functions of campaign messages. An established pattern tends to confess and defend more than challengers, while challengers tend to attack more than incumbents, which also confirmed. Second, political communication on Facebook during the 2012 Taiwanese elections can be observed in two forms: 1.0 message (candidate message), which is more focused on policy on characters, and 2.0 messages (candidate's message is highlighted by interactions on Facebook), which emphasizes character more than policy.

Jokowi's own YouTube account that already has 496,159 subcriber and the total average viewers of each video are 20 thousand to 2.2 million viewers. This proves that Jokowi's YouTube social media account is very much loved by the public.

Dichanel Youtube, Jokowi presents daily activities as the president of RI, for example, home activities and Jokowi's work activities as Head of State.
Through this Youtube media, Jokowi indirectly conducts a political image where it is very useful for his political scene in Indonesia.

According to Firmanzah [8], image is needed to distinguish one political party from another political party, as a positioning strategy. It is a construction of people's representation and perception of a political party or individual regarding all matters related to political activities. According to Firmanzah, although political images are not real, they can be created, built, and strengthened. Political image has the power to motivate actors or individuals to do something. It can influence public opinion while spreading certain meanings. A good political image will have a positive effect on voters in order to vote in the elections. The brand itself is a name that produces a psychological impression as stated by Aleena Wheleer in the book Designing, Brand, Identity [9].

According to Dan Nimmo \& Sanders [10], Personal images in politics have at least three benefits; first, how it is true or false, complete or incomplete knowledge of people about politics, it provides a way to understand certain political events. Second, general likes or dislikes in one's image of politics present a basis for valuing political objects. Third, a person's selfimage provides a way to connect himself with others. A person's image helps in understanding, evaluating, and identifying events, ideas, goals, or political leaders. Imagery helps provide subjective, acceptable reasons for why things appear as they appear, political preferences, and associating with others. People do not only have a reason to act but also have a need to act.

To build a political image, there are several things that need to be realized by Firmanzah [8]. First, it takes a relatively long time to build an image. The public needs a long period to be able to see the suitability of their political patterns and flow with a political party. Second, building an image requires consistency from everything that is experienced by political parties or individuals concerned such as work programs, platforms, reputation. When there is ambiguity or inconsistency, the image recorded by the public becomes incomplete. Third, political image is the impression and public perception of what is done by political actors. Political actors must be able to immerse their image and reputation in the minds of the people. Fourth, the political image is in the public awareness that comes from the collective memory of the community. All things done by political actors will not just disappear but will be recorded in public memory.

Electability in political meaning is the level of electability of a party, or candidate associated with the electoral process. The term popularity and electability in society is often equated, even though both have different meanings and connotations even though they have great closeness and correlation. Popularity is more 
related to the well-known of people, both in a positive or negative sense.

Based on the description above, this researcher's problem statement is how big is the influence of President Jokowi's Vlog on Political Imaging and Electability Towards the 2019 Presidential Election? The research method used was a survey by collecting techniques through closed interviews (questionnaires). The number of respondents were 221 students with an error margin of $2.2 \%$ and a confidence level of $95 \%$.

\section{METHOD}

This research is a quantitative research. Quantitative research is research that describes or explains a problem inwhich the results can be generalized, thus this research is not too concerned with the depth of data or analysis. In this quantitative study, researchers are more concerned with aspects of the breadth of the data so that the data or research results are considered to be a representation of the entire population. This study aims to test theories or hypotheses, support or reject theories. Data is only a means of confirming a theory or a theory proven by data [11]

In this research, the researcher applied quantitative descriptive analysis. The researcher described the data that has been collected, without intending to make conclusions. Through this descriptive analysis could describe or analyze a statistical result of the study. However, it did not use to make broader or general conclusions. This descriptive analysis described each variable, namely variable $\mathrm{X}$ (vlog jokowi), variable Y1 (political image) and variable Y2 (electability). In this analysis, calculations were used to find out the frequency level of the answer score of each indicator of the variable dimensions using SPSS version 24.
The next stage of the analysis was the data normality test. Data normality test is performed to find out whether the data under study is normally distributed or not. If the data is normally distributed, then hypothesis testing can be done. Testing normality in research used the Kolmogorov Smirnov test, because the number of respondents $>50$ people, testing is done by SPSS 24 application and the basis for decision making by seeing the significance $\alpha=5 \%$ with the provisions

a. Probability> 0.05 , then the data is normally distributed.

b. Probability $<0.05$ then the data is not normally distributed.

The next analysis technique was the correlation test. Correlation test is used to find a relationship and prove the hypothesis of a relationship between two variables if the data of the two variables are in the form of likert, and the source of the data of the two variables is the same. Correlation test analysis that can be done, namely the Pearson Product Moment correlation test. The Pearson Product Moment correlation formula (Sugiyono, 2007: 273), as follows:

$$
r_{x y}=\frac{n \sum x y-\sum x \sum y}{\sqrt{\left(\sum x^{2}-\left(\sum x\right)^{2}\right)\left(n \sum y^{2}-\left(\sum y\right)^{2}\right)}}
$$

Notes:

rxy $=$ Pearson correlation coefficient ( $r)$ between variable $\mathrm{X}$ and $\mathrm{Y}$

$\mathrm{n}=$ Number of Respondents

$\mathrm{x}=$ Score obtained by subjects of all items

$\mathrm{y}=$ total score obtained from all items

\section{RESULT}

The calculation of the correlation coefficient in this study examines the relationship between jokowi vlog (variable $\mathrm{x}$ ) to political image (variable $\mathrm{y} 1$ ) and electability (y2). This can be seen in the following table:

Table-1: Correlation Coefficient Test Results

\begin{tabular}{|c|c|c|c|c|}
\hline \multicolumn{5}{|c|}{ Correlations } \\
\hline & & JOKOWI'S VLOG & POLITICAL IMAGE & ELECTABILITY \\
\hline \multirow[t]{3}{*}{ JOKOWI'S VLOG } & Pearson Correlation & 1 & $.593^{* * *}$ & $.393^{* *}$ \\
\hline & Sig. (2-tailed) & & .000 & .000 \\
\hline & $\mathrm{N}$ & 221 & 221 & 221 \\
\hline \multirow[t]{3}{*}{ POLITICAL IMAGE } & Pearson Correlation & $.593^{* *}$ & 1 & $.443^{* *}$ \\
\hline & Sig. (2-tailed) & .000 & & .000 \\
\hline & $\mathrm{N}$ & 221 & 221 & 221 \\
\hline \multirow[t]{3}{*}{ ELECTABILITY } & Pearson Correlation & $.393^{* *}$ & $.443^{* * *}$ & 1 \\
\hline & Sig. (2-tailed) & .000 & .000 & \\
\hline & $\mathrm{N}$ & 221 & 221 & 221 \\
\hline
\end{tabular}

From the table above, it can be explained that the relationship between Jokowi's vlog variable and political image has 0.593 , and the relationship between
Jokowi's vlog variable and electability is 0,393 . This shows that the relationship between Jokowi's vlog variable and political image is strong because it is at 
correlation interval $0.5-0.75$. While the relationship between Jokowi's vlog variable and electability is quite significant because it is in the $0.25-0.5$ correlation interval. The coefficient in this study shows a positive number, then the three variables have a direct relationship. This means that if the value of $\mathrm{X}$ is high, then the values of the variables Y1 and Y2 will be high too.

The significance of the relationship between these three variables can be analyzed with the following conditions:

- If the probability is $<0.05$ then the relationship between the two variables is significant.
- If the probability is $>0.05$ then the relationship between the two variables is not significant.

The table shows the probability of the relationship between the jokowi vlog variable, political image and electability is 0,000 . The probability between these variables is $<0.05$ so it can be said that the relationship between the two variables is considered significant.

After knowing that there is a strong and significant relationship between the independent variable, Jokowi's vlog, and the dependent variable, political image and electability. The next researcher aims to see how much the independent variable can influence the dependent variable.

Table-2: Determination coefficient test results

\begin{tabular}{|l|l|l|l|l|}
\hline \multicolumn{5}{|c|}{ Model Summary $^{\mathbf{b}}$} \\
\hline Model & $\mathrm{R}$ & R Square & Adjusted R Square & Std. Error of the Estimate \\
\hline 1 & $.593^{\mathrm{a}}$ & .352 & .349 & 5.286 \\
\hline \multicolumn{7}{|l|}{ a. Predictors: (Constant), JOKOWI'S VLOG } \\
\hline
\end{tabular}

From the table above, it can be seen that the value of $\mathrm{R}$ (correlation coefficient) shows a value of 0.593. If it is included in the coefficient of determination equation, the results are:

$\mathrm{Kd}==(\mathrm{R}) 2 \mathrm{X} 100 \%$

$$
\begin{aligned}
& \mathrm{Kd}=(0,593) 2 \times 100 \% \\
& \mathrm{Kd}=35,2 \%
\end{aligned}
$$

This means that $35.2 \%$ of the political image variable is the contribution of the Jokowi vlog variable.

Table-3: Determination coefficient test results

\begin{tabular}{|l|l|l|l|l|}
\hline \multicolumn{5}{|c|}{ Model Summary $^{\mathbf{b}}$} \\
\hline Model & $\mathrm{R}$ & R Square & Adjusted R Square & Std. Error of the Estimate \\
\hline 1 & $.393^{\mathrm{a}}$ & .155 & .151 & 4.237 \\
\hline \multicolumn{5}{|l|}{ a. Predictors: (Constant), VLOG JOKOWI'S VLOG } \\
\hline
\end{tabular}

From the table above it can be seen that the value of $\mathrm{R}$ (correlation coefficient) shows a value of 0.393. If it is included in the coefficient of determination equation, the results are:

$$
\begin{aligned}
& \mathrm{Kd}==(\mathrm{R}) 2 \times 100 \% \\
& \mathrm{Kd}=(0,393) 2 \times 100 \% \\
& \mathrm{Kd}=15,5 \%
\end{aligned}
$$

This means that $15.5 \%$ electability is the contribution of the jokowi vlog variable. While the remaining $49.3 \%$ can be explained or influenced by other variables which are not examined by the researcher.

In addition to testing the correlation cofesien, this study also tested the simple linear regression, in order to find out how much the strength of the independent variable (variable $\mathrm{X}$ ) is related to the

\begin{tabular}{|c|c|c|c|c|c|c|}
\hline \multicolumn{7}{|c|}{ Coefficients $^{\mathrm{a}}$} \\
\hline \multirow{2}{*}{\multicolumn{2}{|c|}{ Model }} & \multicolumn{2}{|c|}{ Unstandardized Coefficients } & Standardized Coefficients & \multirow[t]{2}{*}{$\mathrm{t}$} & \multirow[t]{2}{*}{ Sig. } \\
\hline & & $\mathrm{B}$ & Std. Error & Beta & & \\
\hline \multirow[t]{2}{*}{1} & (Constant) & 10.445 & 1.880 & & 5.557 & .000 \\
\hline & JOKOWI'S VLOG & .462 & .042 & .593 & 10.907 & .000 \\
\hline a. & Dependent Variable & OLITI & MAGE & & & \\
\hline
\end{tabular}
dependent variable (variable Y). Both variables were processed using linear regression analysis in SPSS version 24.

Table-5: Results of the Simple Linear Regression Test Variable of Jokowi's Vlog on Political Image

The equation obtained from the table above is:

The constant value a (variable Y1: political image) is 10.445 and the constant value $\mathrm{b}$ (variable $\mathrm{X}$ : jokowi's vlog) is 0.462 . From these results obtained a regression equation:

$$
\begin{aligned}
& Y=a+b X \\
& Y=10,445+0,462 X
\end{aligned}
$$


This states that if $\mathrm{X}$ increases in value by 1 (unit), then Y will increase in value by 0.462 .

Table-6: Results of the Simple Linear Regression Test Variable of Jokowi's Vlog on Political Images (Perdimensi)

\begin{tabular}{|c|c|c|c|c|c|c|}
\hline & & & Coefficie & & & \\
\hline & & Unstanc & ed Coefficients & Standardized Coefficients & $\mathrm{t}$ & Sig. \\
\hline & & $\mathrm{B}$ & Std. Error & Beta & & \\
\hline 1 & (Constant) & 10.670 & 1.835 & & 5.815 & .000 \\
\hline & Vlog content & .980 & .127 & .650 & 7.722 & .000 \\
\hline & Vlog quality & -.150 & .196 & -.071 & -.769 & .443 \\
\hline & Attention & .222 & .251 & .064 & .886 & .377 \\
\hline
\end{tabular}

Through the table above, the researcher also wants to show how much the strength of the $\mathrm{X}$ variable dimension (Jokowi's vlog dimension) is related to the Y1 variable (political image). It can be seen that the constant value of $\mathrm{b}$ (variable dimension $\mathrm{x}$ : jokowi's $v \log$ ) is the largest dimension of vlog content, which is equal to $0.980(\mathrm{Y}=10.670+0.980 \mathrm{X})$. This states that if $\mathrm{X}$ increases in value by 1 (unit), then $\mathrm{Y}$ will increase by 0.980 .

The linear regression test variable of jokowi's vlog and electability are:

Table-7: Results of the Simple Linear Regression Test of Jokowi's Vlog Variable on Electability

\begin{tabular}{|c|c|c|c|c|c|c|}
\hline \multicolumn{7}{|c|}{ Coefficients $^{\mathbf{a}}$} \\
\hline \multirow{2}{*}{\multicolumn{2}{|c|}{ Model }} & \multicolumn{2}{|c|}{ Unstandardized Coefficients } & Standardized Coefficients & \multirow[t]{2}{*}{$\mathrm{t}$} & \multirow[t]{2}{*}{ Sig. } \\
\hline & & $\mathrm{B}$ & Std. Error & Beta & & \\
\hline \multirow[t]{2}{*}{1} & (Constant) & 5.464 & 1.507 & & 3.626 & .000 \\
\hline & JOKOWI'S VLOG & .215 & .034 & .393 & 6.328 & .000 \\
\hline
\end{tabular}

The equation obtained from the table above is:

The constant value a (variable Y2: electability) is 5.464 and the constant value $\mathrm{b}$ (variable $\mathrm{X}$ : jokowi's vlog) is 0.215 . From these results obtained a regression equation:

$$
\begin{aligned}
& Y=a+b X \\
& Y=5,464+0,215 X
\end{aligned}
$$

This states that if $\mathrm{X}$ increases in value by 1 (unit), then $\mathrm{Y}$ will increase in value by 0.215 .

\begin{tabular}{|c|c|c|c|c|c|c|}
\hline \multicolumn{7}{|c|}{ Coefficients $^{\mathrm{a}}$} \\
\hline \multirow{2}{*}{\multicolumn{2}{|c|}{ Model }} & \multicolumn{2}{|c|}{ Unstandardized Coefficients } & Standardized Coefficients & \multirow[t]{2}{*}{$\mathrm{t}$} & \multirow[t]{2}{*}{ Sig. } \\
\hline & & $\mathrm{B}$ & Std. Error & Beta & & \\
\hline \multirow[t]{4}{*}{1} & (Constant) & 4.831 & 1.508 & & 3.203 & .002 \\
\hline & Dimension_X1 & .180 & .104 & .170 & 1.724 & .086 \\
\hline & Dimension_X2 & -.014 & .161 & -.010 & -.088 & .930 \\
\hline & Dimension_X3 & .757 & .206 & .311 & 3.678 & .000 \\
\hline
\end{tabular}

Table-8: Results of the Simple Linear Regression Test of Jokowi's Variable on Electability (Dimension)

Through the table above, the researcher shows the magnitude of the $\mathrm{X}$ dimension (Jokowi's vlog dimension) is related to the Y2 (electability) variable. It can be seen that the constant value of $b$ (variable dimension $\mathrm{x}$ : vlog jokowi) is the greatest dimension of Attention, which is $0.757(\mathrm{Y}=4.831+0.757 \mathrm{X})$. This states that if $\mathrm{X}$ increases in value by 1 (unit), then $\mathrm{Y}$ will increase by 0.757 .

To test the hypothesis the researchers used the "T test" to see whether there was an influence of the variable $\mathrm{x}$ (Jokowi's vlog) on the dependent variables
Y1 (political image) and Y2 (electability). With the following hypothesis

Ha1: There is an influence between jokowi's vlog on jokowi's political image

$\mathrm{Ha} 2$ : There is an influence between jokowi's vlog on electability in the 2019 election

Ho1: There is no influence between the jokowi's vlog on the jokowi's political image

Ho2: There was no influence between Jokowi's vlog on electability in the 2019 elections

The hypothesis test is illustrated in the following table. 
Table-9: Hypothesis Test Results 1

\begin{tabular}{|l|l|l|l|l|l|l|}
\hline \multicolumn{7}{|c|}{ ANOVA $^{\mathrm{a}}$} \\
\hline \multicolumn{2}{|c|}{ Model } & Sum of Squares & df & Mean Square & F & Sig. \\
\hline \multirow{2}{*}{1} & Regression & 3323.472 & 1 & 3323.472 & 118.956 & $.000^{\mathrm{b}}$ \\
\cline { 2 - 7 } & Residual & 6118.546 & 219 & 27.939 & & \\
\cline { 2 - 7 } & Total & 9442.018 & 220 & & & \\
\hline
\end{tabular}

Table-10: Hypothesis Test Results 2

\begin{tabular}{|c|l|l|l|l|l|c|}
\hline \multicolumn{7}{|c|}{ ANOVA $^{\text {a }}$} \\
\hline \multicolumn{2}{|c|}{ Model } & Sum of Squares & df & Mean Square & F & Sig. \\
\hline \multirow{2}{*}{1} & Regression & 719.128 & 1 & 719.128 & 40.050 & $.000^{\mathrm{b}}$ \\
\cline { 2 - 7 } & Residual & 3932.338 & 219 & 17.956 & & \\
\cline { 2 - 7 } & Total & 4651.466 & 220 & & & \\
\hline \multicolumn{7}{|l|}{ a. Dependent Variable: ELEKCABILITY } \\
\hline
\end{tabular}

From the above results, it can be concluded that the value of t test $1(10.907)>t$ table (1.652), and the value of t test 2 (6.328)> t table (1.652). This figure shows that both Ho were rejected and both Ha were accepted. This means that there is an influence of Jokowi's vlog on political image and electability ahead of the 2019 presidential election. The influence is positive and significant.

\section{DISCUSSION}

President Joko Widodo has a unique way to greet the public, for example blusukan and via vlog. President Jokowi's vlog does not merely contain serious matters such as when inaugurating the people's market, but it is also filled with state events such as when Raja Salman visited Indonesia. Even trivial things were uploaded, like when the pet goat was breeding.

Jokowi's Vlog is one of the media used by President Jokowi in conveying his performance as the president of the Republic of Indonesia and this is also as a personal media campaign containing messages that can build his political image and gain the interest of voters to re-elect him as the next President of Indonesia at the 2019 Presidential Election through the formation of electability that has been built through the vlog.

Political communication is important to show how a leader interacts with his people. What President Joko Widodo (Jokowi) did is certainly different from his predecessor, Susilo Bambang Yudhoyono (SBY), they chose an contradiction approach. SBY was a president who enforces protocols. For example, when SBY reprimanded the sleeping children and asked them to be awakened because he wanted to continue the speech.

Jokowi, on the other hand, likes to make jokes, laugh out loud, even he is not hesitate to make physical contact with anyone, for example, when visiting a number of Islamic boarding schools, Jokowi invited students to answer quizzes that the answer invited laughter. Instead of rebuking or scolding those who are sleepy, Jokowi can liven up the atmosphere with his friendly attitude.

Jokowi's way is similar to Obama approach (former President of the USA) to image himself as president. If the presidents of the republican party are very rigid and seem very distant, Obama, who is from the Democratic Party, can be easily found on television shows, hanging out at fast food restaurants, or even inviting pop musicians to hold concerts in the White House. This method proved positive to make Obama a populist and flexible president. The benefits can be seen from young voters who fall in love with Obama's relaxed attitude.

The channel of President Joko Widodo was first registered on Youtube on May 6, 2015. However, he uploaded a video on YouTube for the first time on July 27, 2016. At the time, he uploaded a video of activities during turba. It contained a matter of advice and development achievements he had done.

From 30 videos uploaded since August 2016, Jokowi only got 21,314 subscribers and 452,138 views. From the subscriber side and viewer this number is far less than the YouTube channel of his son, Kaesang Pangarep. Kaesang had already received 127,788 subscribers and 7 million views. In fact, Kaesang has only uploaded nine videos since March 7, 2016.

Whereas, the Response is the response of organisms or viewers, here the viewers who were successfully stimulated by the "stimulus" will give a response in the form of their assessment of President Jokowi and their interest in electing President Jokowi again at the 2019 Presidential Election later. Based on 
the results obtained by the researcher, the researcher found that $70 \%$ of the audience knew the image of President Jokowi as a President who was close to the community and possessed the nature desired by the community, and also they agreed to elect President Jokowi in the 2019 Presidential Election later.

\section{CONCLUSION}

Whereas, the Response is the response of organisms or viewers, here the viewers who were successfully stimulated by the "stimulus" will give a response in the form of their assessment of President Jokowi and their interest in electing President Jokowi again at the 2019 Presidential Election later. Based on the results obtained by the researcher, the researcher found that $70 \%$ of the audience knew the image of President Jokowi as a President who was close to the community and possessed the nature desired by the community, and also they agreed to elect President Jokowi in the 2019 Presidential Election later.

\section{REFERENCES}

1. Alujevic, Lucia Vesnic. 2014. YouTube: A Political Advertising Tool? A Case Study of the Use of YouTube in the Campaign for the European Parliament Elections 2009. Taylor \& Francis Group Journal

2. Chen Ping, Ching. Application of the StimuliOrganismResponse (S-O-R) Framework to Online Shopping Behavior. College of Business Administration, Kangwon National University, Chuncheon, Republic of Korea, Journal Journal of Internet Commerce, 13:159-176, 2014 Taylor \& Francis Group

3. Chun Wen, Wei. 2014. Facebook political communication in Taiwan: 1.0/2.0 messages and election/ post-election messages. Shih Hsin University, Taiwan, Chinese Journal of Communication, 2014, Publisher: Routledge Informa Ltd Registered in England and Wales.

4. Firmansyah (2010), 2010. Marketing Politik: Persaingan, Legitimasi Kekuasaan dan Marketing Politik. Jakarta : Yayasan Obor Indonesia.

5. Himelboim, Itai dkk. 2012. Social Media and Online Political Communication: The Role of Interpersonal Informational Trust and Openness. Journal of Broadcasting \& Electronic Media 56(1), 2012, pp. 92-115, Taylor \& Francis Group

6. Hyowon Hyun, Jungkung Park, Tianbao Ren dan Hyunin Kim (2018) The role of ambiances and aesthetics on millennials' museum visiting behavior, Arts Marketing; Bingley Vol. 8, Iss. 2, (2018): 152-167. DOI:10.1108/AAM-04-2017-0006

7. Nimmo, Dan \& Sandrs, Keith R (1981) Handbook of Political Communication, Sage Publication

8. Syaifuddin. The Influence Of Political Exposure In Digital Media To The Participation Of Prospective Voters For Demokrat Party In East Java Ahead Of The Election 2019. International Journal of Scientific and Research Publications, Volume 9, Issue 12, December 2019

9. Umer, Muhammad: Attiq, Saman: Jalil Hasan. Determinants of Online Consumers' Compulsive Buying Behavior: An S-O-R Approach in SNS Context, Journal of Business \& Economics; Islamabad Vol. 10, Iss. 2, (Jul-Dec 2018): 105-132.

10. Umonrat Segson and Chai Ching Tan, Application of Stimulus-Organism-Response (S-O-R) to Study Consumer Behavior of Upscale Restaurant in Northen Thailand, Asian Academic Society International Conference (AASIC) 2018. 